\title{
Legal Protection of E-Commerce Consumers Through Privacy Data Security
}

\author{
Sugeng ${ }^{1, *}$ Annisa Fitria ${ }^{2}$ \\ ${ }^{1}$ Faculty of Law, University of Bhayangkara Jakarta Raya 1 \\ ${ }^{2}$ Faculty of Law, University of Esa Unggul 2 \\ *Corresponding author. Email: sugeng@dsn.ubharajaya.ac.id
}

\begin{abstract}
The development of e-commerce has increased significantly, along with the increasing number of internet and social media users in Indonesia. The rapid growth of e-commerce has gradually changed the way consumers purchase goods and services. The most dominant use of the internet is to offer a variety of products. On the one hand, the growth of electronic transactions has had a positive impact, as it provides convenience, comfort, efficiency, flexibility, and low costs for businesses and consumers. On the other hand, electronic transactions also increase the risks and uncertainties that harm consumers. This article aims to examine what risks arise and whether consumer protection laws are sufficient to address the issue. This study uses the normative juridical method to find the norms and principles of law that apply today. The legal materials that are the object of study are laws and regulations in the field of consumer protection, e-commerce, and electronic transactions. In e-commerce transactions, consumers face a higher risk than business actors (merchants), because consumer rights are in a weak and vulnerable position. The third party's data can be stolen when businesses and consumers communicate. The research findings showed that the current consumer protection law is not sufficient to protect e-commerce consumers, so it needs to be improved to accommodate changes and current business dynamics. Personal data protection needs to be promoted as an instrument to protect the interests of e-commerce consumers.
\end{abstract}

Keywords: consumer, e-commerce, data security.

\section{INTRODUCTION}

The use of information and communication technology has changed the style and habits of society in various fields of life, such as education, politics, and economic activities. In line with these changes, the digital economy or Electronic Commerce (E-Commerce) is also growing dynamically. Among Southeast Asian countries, Indonesia has a very promising e-commerce business potential. Supported by a large population, massive technological infrastructure development, and increasing number of active internet users, e-commerce in Indonesia has witnessed the highest growth among other countries in the region.[1]

The development of e-commerce is a new pillar of national economic growth that should be maintained for sustainability. In this case, the Indonesian government has issued policies and regulations related to the development of information technology infrastructure and its use in the economic sector. Strengthening ecommerce regulations is urgent for at least three reasons.[2] First, information technology must be used as a support for economic growth. Second, the old regulations that are not appropriate need to be changed to accommodate the needs of the community, and, third, the community needs to be protected from the negative impact of the use of technology that is against the law.

Amid the Covid-19 pandemic which has been going on for 7 months, the need to shop online is getting real. Instead, people use information technology to facilitate all their activities. This kind of situation forces everyone to be familiar with various digital applications.[3] In one device, various applications serve public consumption through cashless services.

The development of e-commerce as described above should be welcomed, because it makes our lives easier and more efficient, and is no longer obstructed by time and space boundaries. On the other hand, the various conveniences presented by the digital economy also bring with them serious problems experienced by the community.[4] Legal cases have sprung up, which are increasingly difficult to resolve due to gaps or inconsistencies in existing regulations. Besides, the public and law enforcers' understanding of the new legal phenomenon is also inadequate to solve the problem. From the description of this problem, this paper intends 
to ask two main research questions, namely: a) How is the legal protection for e-commerce consumers, b) Can personal data security be used as an instrument for ecommerce consumer protection?

Studies on this theme have been carried out by other researchers, emphasizing different points of view. Three of the studies will be described as follows: First, research that examines buying and selling transactions through social media. This study found that buying and selling online through social media resulted in a reduced level of vigilance in buying and selling transactions, even neglected, given the ease with which the online shopping facilities are available. This is proven by the number of reports and cases of fraud online. This is because consumers or buyers cannot meet face to face with the seller, so the belief system becomes the main capital in every online buying and selling transaction.[5]

Second, the research that examine e-commerce in a consumer protection perspective. This study states that consumer protection is regulated in several laws and regulations, namely, Law No. 8 of 1999 concerning Consumer Protection (UUPK), the Civil Code (KUHPer), especially articles relating to agreements, and Law No. 11 of 2008 concerning Information and Electronic Transactions (UU ITE/ITE LAW), especially regarding transaction files that can be used as evidence in court.

Third, research on consumer protection in buying and selling transactions via the internet. This study confirms that the ITE Law also has a role to provide protection for the rights of consumers who make transactions, as well as rights mentioned in Article 4 UUPK. Consumer rights in e-commerce transactions can be in the form of privacy, accuracy, property, and accessibility in digital use signature. Two legal remedies can be taken if there is a default in the sale and purchase transaction via the internet, namely through a court which is possible if the parties to the agreement have not voted out-of-court dispute resolution efforts or out-of-court dispute resolution efforts are unsuccessful and out-of-court dispute resolution can be pursued through the consumer dispute resolution agency (BPSK).[6]

The three studies only use the ITE Law, UUPK, and KUHPer as legal instruments for consumer protection. all three represent similar research because they use the currently applicable regulations. In the future, a more serious study is needed on the possibility of using private data protection laws to protect consumer rights, especially e-commerce consumers.

In part II, the research methods used are described, and it describes the main legal materials and supporting documents that have been reviewed. Then, in part IV, the discussion begins with the development of ecommerce in Indonesia, supporting business ecosystems, and applicable regulations. The explanation regarding the discussion of personal data protection is directed at the discourse of the draft law, in particular several important themes related to consumer protection. Furthermore, in section IV, a summary of the discussion is presented, and recommendations regarding the importance of further research in the field of electronic transaction-based consumer protection in various business sectors.

\section{RESEARCH METHOD}

This study uses a normative and comparative juridical approach. This approach is used to hold legal materials and other supporting documents. Through this approach, this study describes consumer protection in electronic transactions. Besides, a comparative juridical approach is needed to examine the legal materials applicable in other countries, which can be studied to enrich the discourse on the formation of new laws in the field of personal data protection. The literature review is carried out by examining relevant printed and electronic documents, including primary legal materials, namely various regulations related to consumer protection in ecommerce, ITE Law, and the draft of the Personal Data Protection Act.

\section{FINDINGS AND DISCUSSION}

\subsection{Development of E-Commerce in Indonesia}

Actually, the e-commerce industry in Indonesia has been growing for a long time. However, the growth started to look significant since 2014. In 2014, the number of e-commerce sales in Indonesia reached USD 1.1 billion. This growth is likely This growth is likely to remain sustainable. [7] The large population makes Indonesia a very potential market. In addition, the government's intensively carried out infrastructure development has helped build a positive business climate. Even without big capital, anyone can now have their own online business. Through careful business planning, everyone has the opportunity to succeed in the online business.

Based on data from the Central Statistics Agency (BPS), the e-commerce industry in Indonesia has increased by $17 \%$ over the last 10 years. Meanwhile, 2018 was the year when the e-commerce business grew the fastest. However, the rapid development of ecommerce in Indonesia actually comes from informal trade or social trade which is driven by small business actors. These small business actors usually use social media such as Facebook, Instagram, and WhatsApp to transact business. 
Graph 1. Projection of Growth of E-Commerce in Indonesia

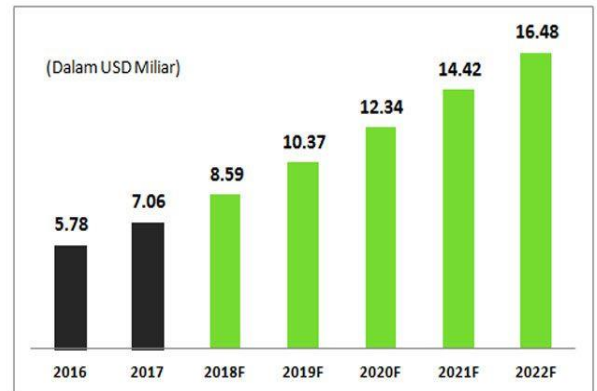

Source: Central Statistics Agency (BPS), 2020.

Graph 1 above shows the sustainable growth of the e-commerce business. Even so, this growth has not been evenly distributed nationally. Because the e-commerce business ecosystem is centered in the cities of the island of Java. All of the e-commerce sales, as much as $40 \%$ comes from informal trade. The number of online sellers continues to increase. It is noted that every year the number of online sellers has doubled. Then, as many as $99 \%$ of these online businesses are classified as microbusinesses. Interestingly, half of the total micro, small, and medium-sized businesses (SMEs) only run their business online without having a physical store.[8]

In other research conducted by Google, the digital economy in Indonesia has reached USD 27 billion.[9] This figure makes Indonesia dominate the first place in Southeast Asia, especially in terms of the number of digital economy transactions. It is estimated that this figure will continue to increase. At least, several things influence this increase. Apart from the fact that Indonesia's population is so large, the demographic bomb explosion that makes Indonesia dominated by the productive age has become even more evident.

The growth of the e-commerce business is supported by three types of business models, namely: a) $\mathrm{C} 2 \mathrm{C}$ (Consumer to Consumer) Business Model; b) B2C (Business to Consumer) Business Model; and c) B2B (Business to Business) Business Model.[10]

\subsubsection{C2C (Consumer to Consumer) Business Model}

In this business model, the existing relationship is between consumers and consumers. This is the essence of the $\mathrm{C} 2 \mathrm{C}$ business model. This business activity generally involves individuals. An individual consumer sells goods or services to other consumers. Due to the small capital, this business model is also very popular. The $\mathrm{C} 2 \mathrm{C}$ business can be further divided into 2 models, namely $\mathrm{P} 2 \mathrm{P}$ or classified and marketplaces. However, even though the scale of this business is small and does not need a business capital loan, the perpetrators can grow to reach a larger business scale.

\subsubsection{B2B (Business to Consumer) Business Model}

This business model is the type most commonly found in the e-commerce market. As the name implies, this business model involves producers with consumers. For this reason, this $\mathrm{B} 2 \mathrm{C}$ model resembles a traditional retail model. One example of a $\mathrm{B} 2 \mathrm{C}$ business model is an online shop. However, currently, this business model is increasingly merging with the $\mathrm{C} 2 \mathrm{C}$ business. This happens because there is an increasingly even reputation assessment. Consumers who have a good sales reputation are also considered credible enough as a business in the form of a business entity. On the other hand, with business capital loans, individual consumers can become larger business actors so that they are quite eligible to be included in the B2C category.

\subsubsection{B2B (Business to Business) Model}

This business model occurs between business and business. The seller only focuses on the business market and does not serve orders from consumers. Generally, this B2B business model is more dominated by service providers. In addition, there are also suppliers of goods. For example, such as manufacturers of office furniture or suppliers of goods needed by the company. Compared to the $\mathrm{C} 2 \mathrm{C}$ or $\mathrm{B} 2 \mathrm{C}$ business models, the $\mathrm{B} 2 \mathrm{~B}$ business market is indeed smaller. However, this does not mean that this business model will only provide a small profit.

\subsection{E-Commerce Consumer Protection}

As a rule of law, the Indonesian government must be present to fulfil a sense of justice for its citizens. Consumer protection is part of human rights. In Article 4 of Law No. 8/1999 on Consumer Protection (UUPK), nine rights of consumers are stated, namely: a) The right to comfort and safety in consuming goods or services; b) The right to choose goods services; c) Right to correct information; d) The right to have their complaints heard; e) Right to advocacy and protection; f) The right to receive guidance and education; g) the right to receive compensation; $h$ ) rights granted in other regulations.[11]

To fulfil these rights, entrepreneurs are obliged to respect the rights of consumers. Among these consumers, are those who make buying and selling transactions online. Theoretically, business actors and consumers who transact online are not legal subjects regulated by the UUPK, so that consumer rights in this category are often violated by business actors. At the global level, the United Nations Commission International Trade Law (UNCITRAL) has established a legal model for E-Commerce in 1996, then revised it in 1998. This legal model contains guidelines for UN member states.[12] UNCITRAL defines e-commerce as follows: 


\begin{abstract}
The term "Commercial" should be given an interpretation so as to cover matters from all relationships of a commercial nature whether contractual or not. Relationship of a commercial nature includes but are not limited to the following transaction for the supply or exchange of goods or services, commercial representation or agency, factoring leasing, construction of work, consultation, engineering, licensing, investment, financing, banking, insurance, exploitation agreement or concession, carriage of goods or passengers by air, sea, rail or road.
\end{abstract}

Referring to this definition, e-commerce includes many activities and broad business potential and becomes a magnet for future economic growth. Furthermore, the definition of e-commerce shows an advantage because it can facilitate the process of distribution, buying, selling, marketing products or services through electronic systems. As per its characteristics, the communication industry includes a global network that allows business people to transact with anyone, anywhere directly.[13]

Based on the Model Law on UNCITRAL, the main factor in electronic transactions is that agreements are made electronically. In this case, digital data serves as a medium for an electronic agreement. The use of digital data as a medium of the agreement will increase business efficiency. However, electronic agreements made by the parties also often cause legal problems, such as those related to the legality and binding strength of the agreement.

The sale and purchase agreement made through the electronic media of the internet is an extension of the concept of a sale and purchase agreement that is in the Civil Code (KUHPer). Conventional trading or buying and selling in civil law is a legal basis through internet agreements. In general, electronic contracts contain at least: a) Identity data of the parties, b). Objects and specifications, c) Electronic transaction requirements, d) Prices and fees, e) Procedure in the event of a cancellation by the parties; f) Provisions that give the injured party the right to be able to return the goods and or request replacement of the product if there is a hidden defect, and g) Choice of electronic transaction settlement law.[14]

The legality of an electronic contract is contained in the provisions of Article 1320 KUHPer, which is an agreement from the parties; the ability of the parties to take legal actions; a certain subject; and a cause that is not forbidden. The legal consequence is that if a trade contract made electronically or e-contract is invalid, it can be canceled and null and void if it is not following Article 1320. The parties in making contracts, especially e-contracts, are expected to use the provisions in Article 1320 of the Civil Code so that the contracts made by these parties become legally valid and legal. The authorized government should make separate rules regarding electronic contracts so that there are stronger rules to regulate e-contract.

\subsubsection{Standard Agreement}

In line with the UNCITRAL Law model, Article 18 paragraph (1) UU ITE confirms, "Electronic transactions that are stated in a contract electronics binds the parties". In line with the UNCITRAL Law model, Article 18 paragraph (1) confirms, Electronic Transactions that are poured into Electronic Contracts bind the parties. Electronic contracts are standard contracts designed, created, determined, duplicated, and distributed digitally through the internet site (website) unilaterally by the contract maker (in this case the business actor), to be closed digitally by the contract closing (in this case the consumer).

The development of electronic transactions shows an unequal relationship between business actors and consumers. Businessmen who sell goods or services online often include standard contracts, which give rise to unequal bargaining power. The terms and conditions contained in the standard contract are made unilaterally by the businessman. They use the standard contract through the website and close the possibility for customers to negotiate.

The unbalanced application of an agreement that creates profit for business actors often appears in the form of a standard agreement/standard clause, because the format and contents have been determined previously unilaterally. An agreement like this is generally included in every agreement document made by one party which is more dominant than the other. It is said to be standard because both the agreement and the clause cannot and cannot be negotiated by other parties. Consumer Protection Law (UUPK) defines standard clauses on Article 1 point 10, namely: "Standard clause is any rules or terms and conditions that are has been prepared and determined in advance unilaterally by the business actor as stated in a document and/or agreement binding and must be fulfilled by consumers".

The use of standard clauses in an agreement is considered not to violate the provisions of civil law, especially those related to the principle of freedom of contract. This is because in the standard agreement not all the contents of the agreement are standardized, it just reduces the existence of the principle of freedom of contract. Consumers are still given the freedom to determine the type of goods, quantity, color, place, time, and other matters relating to the object of the agreement. In this case, consumers are still given the freedom to make agreements in certain matters relating to the object of the agreement. The problem is that there is an exoneration clause in a standard agreement that transfers the responsibility of the businessman.

The exoneration clause is a prerequisite specifically exempt entrepreneurs from responsibility for adverse consequences, arising from the implementation of the agreement. Exoneration clauses can be derived from 
formulas entrepreneurs unilaterally, can also come from the formulation of articles of law. Clause exoneration of the entrepreneur's formula is burdensome proof to consumers, that consumers innocent and this is what makes.[15]

According to Munir Fuady, the exoneration clause is a clause in the contract which exempts or limits the responsibility of a party in case of default, even though according to law, this responsibility should be borne by him. Technically juridical, expression clause in a contract is usually done through three methods as follows:

1) Reduction method or even elimination of obligations laws that are usually charged to one of the parties;

2) Reduction method or even removal against legal consequences due to improper implementation of obligations;

3) Creating a certain obligation to one of the insider's contract.

The use of standard clauses in an agreement arises from the need that exists in the community itself, that in a business relationship that requires a deed that is quite complicated and costs a lot of money and cuts operational costs required and shortens the time. However, in its application, the desire to save operational costs and shorten the time in agreeing often creates conflicts that arise during the process of implementing the agreement.

Parties in a weak position tend to just accept and sign the agreement because he has no bargaining power to change the contents of the contract. To achieve equality. The objectives of the agreement to be achieved by the parties must be clearly formulated and not have multiple interpretations. Thus, the potential for misunderstanding can be reduced as early as possible.

The legal relationship that arises between mutually binding parties has legal consequences that must be obeyed and carried out by both parties. The existence of this relationship begins with an agreement with the goals to be achieved. Thus, good faith, honesty, and openness of the parties related to the matters agreed upon along with the risks that may be experienced in the process of implementing the agreement are some of the most important things for parties to do in the contractual design and implementation process so that it is expected to be able to produce an agreement relationship. fair and proportionate.

\subsubsection{Standard Clause on E-Commerce Transactions}

The use of information technology in commerce is considered to have advantages and conveniences compared to conventional systems. The advantages and ease of using e-commerce include:

1) Trade transactions become more effective and efficient;

2) Trade transactions become more efficient, productive, and competitive;

3) More speed to consumers;

4) Reducing administrative costs;

5) Minimizing problems resulting from differences in culture, language and trade practices;

6) Improve logistics distribution; and

7) Enable small companies to sell their products globally.

Besides having various conveniences, e-commerce transactions also raise various legal problems. One form of the problematic application of buying and selling in e-commerce is the stipulation of standard conditions/ standard clauses by business actors to consumers so that consumers cannot do anything except accepting or rejecting standard clauses that have been set by business actors in selling. the purchase they want, especially the sale and purchase agreement through e-commerce.

Standard clauses in e-commerce transactions, entrepreneurs are required to follow procedures that have been determined in the laws and regulations, namely UUPK. As affirmed in Article 48 paragraph (2) of the Government Regulation of the Republic of Indonesia Number 82 of 2012 concerning Implementation of Electronic Systems and Transactions (PP PSTE), that "electronic contracts made with standard clauses must comply with the provisions regarding standard clauses as regulated in the regulation.

Based on these provisions, the seller should pay attention to the rights of consumers as the party who uses the goods or services sold so that there is a balance between the seller and the buyer and the seller not only for profit, but the seller also practices the rights of the seller consumer rights. The existence of buyers in ecommerce transactions is passive, and only given the freedom to choose yes or no "take it or leave it".

Even though the electronic contract for the formation is only made unilaterally by the seller, the standard clause must meet the values of justice. Balance and proportionality in the making. This is a form of legal protection provided by the legislators so that justice for both parties occurs. Another form of protection for consumers contained in Article 49 PP PSTE is an obligation for business actors to provide a time limit for consumers to return goods sent if they are not in accordance with the agreement or there is a hidden flaw. 
The characteristics of standard clauses must be understood by consumers, especially in agreements that use electronic platforms. Therefore, PP PSTE has protected consumers in the form of an obligation for sellers to provide complete and correct information, as stipulated in Article 49 paragraph (1) PP PSTE states "Business actors offering products through an electronic system are required to provide complete and correct information. These norms are related to the terms of the contract, the manufacturer and the product offered.

Consumer protection in e-commerce is an important aspect to pay attention to, because some of the typical characteristics of e-commerce will place consumers in a vulnerable position, such as:[16]

1) Companies on the internet (the internet merchant) do not have a physical address in a certain country, so this will make it difficult for consumers to return products that are not as advertised;

2) Consumers find it difficult to obtain guarantees to get local aftersale service or repair; and

3) Products purchased by consumers may or may not be compatible with local requirements.

\subsubsection{Dispute Resolution Mechanismes in E- Commerce Activities}

To strengthen protection for consumers, the UUPK mandates the establishment of a Consumer Dispute Resolution Agency (BPSK) based on Article 49 paragraph (1) of the UUPK. Apart from that, the government also recognizes the Non-Governmental Organization for Consumer Protection (LPKSM) based on Government Regulation of the Republic of Indonesia Number 59 of 2001 concerning Non-Governmental Organization for Consumer Protection. It is hoped that the existence of BPSK and LPKSM can make a major contribution to consumer protection as well as become the foremost locomotive in fighting for consumer rights.

The existence of BPSK and LPKSM has been unable to guarantee comprehensive protection for e-commerce consumers. This can be seen from the many consumers who feel that their rights are not protected even though it has been regulated in the UUPK. As a non-structural institution domiciled in the District Municipality, BPSK is only able to solve consumer problems in the realm of before going to court. This institution cannot solve all consumer problems, considering that BPSK's authority is only limited to resolving consumer disputes outside the court, either through mediation, arbitration, or consolidation.[17]

Apart from BPSK, consumer advocacy is also carried out by LPKSM, a non-governmental organization engaged in consumer protection. Before carrying out its duties, this LPKSM must be registered and get recognition from the government. Referring to Article 44 paragraph (3) of the UUPK, the existence of the LPKSM with its fairly comprehensive task still has several shortcomings, one of which is not being able to do advocacy or provide services legal assistance to consumers at court directly.

As the master regulation for consumer protection, the UUPK provides protection for consumers and business actors. These provisions can be seen by the existence of Articles 4 and 5 of the UUPK, which not only explicitly guarantee consumer rights, but also regulate the obligations of consumers that must be fulfilled. Otherwise, article 6 and 7 of the UUPK provide protection and regulation of the rights and obligations of producers.[18]

Consumer protection by the state through UUPK, has not been able to reach consumer protection as a whole.[19] Therefore, a more adequate regulation is needed to protect consumers both inside and outside the court. One of the things that can be done is to revise the UUPK, especially the authority of BPSK and LPKSM, at this time the provision is deemed unable to provide better consumer protection.

\subsubsection{Strengthening the Online Dispute Resolution Mechanism}

The rapid advancement of internet technology cannot be matched by legal reforms, this can be seen from the absence of explicit legal certainty regarding online dispute resolution in Indonesia. Conventional business dispute resolution is generally resolved through court or litigation. The litigation process tends to lead the opposing parties being dragged away from the concept of integration which is a win-win solution but rather a win-lose solution. Conventional dispute resolution takes a long time and is detrimental to justice seekers in all aspects, especially if it is in business activities because it causes a high-cost economy and depletes the potential and resources of the disputing parties. Essentially, business activities require fast, lowcost dispute resolution and informal procedures.

Online dispute resolution (ODR) provides a very good solution to resolve trade disputes that are separated by geographical locations, even between countries. The increasing interaction of society with information technology devices has led to conventional trade switching to a more modern system by combining law, economy, management, and technology.[20] The use of information technology in the dispute resolution system helps parties, who are located across countries, thus opening up new alternatives for justice seekers (justiciable) in resolving their disputes.

Online Dispute Resolution is the use of information and communications technology to help parties manage, 
transform and resolve their conflicts. Inspired by the existence of Alternative Dispute Resolution (ADR), ODR emerged as a variant of ADR. So it can be said that ODR is an implementation of ADR through ICT. Currently, there are at least 4 (four) forms of ODR, as follows:[21]

1) Online settlement, using a special system to settle financial claims automatically;

2) Online arbitration, using the website to resolve disputes with the help of qualified arbitrators;

3) Online resolution of consumer complaints, using email to deal with certain types of consumer complaints; and

4) Online mediation.

Online dispute resolution is carried out by the parties within the territory of national borders (borderless) and across geographies without having to meet face to face. Online dispute resolution has various forms of methods, namely online negotiation, online mediation, online arbitration. Online dispute resolution has been conceptualized in Indonesian legislation. This can be seen in the laws that apply to positive law in Indonesia, including Law Number 30/1999 concerning Arbitration and Alternative Dispute Resolution, UU ITE, and Law Number 7 of 2014 concerning Trade. The three laws are "lex generale" able to cover ODR in Indonesia.[22]

It should be noted, the main cause of the emergence of an imbalance in bargaining position between producers and consumers is due to the low technical skills of consumers and their limited ability to deal with ICT. Most consumers are also not aware of the existence of laws regulating ODR. Thus, it is time for all interested parties to improve consumer education and empowerment, which are the main principles of protecting consumer rights.

\subsection{Personal Data Security as a Consumer Protection Instrument}

Personal data protection laws evolve along with the development of technology itself, particularly ICT. As mentioned earlier, data protection was born in Europe as a result of the absence of a clear definition of privacy and personal life, which is governed by the provisions of Article 8 of the European Convention. The right to data protection itself aims to protect individuals in the information society era.[23]

The first country that passed the Data Protection Act was Germany in 1970, followed by Britain in the same year, and then several other European countries, such as Sweden, France, Switzerland, and Austria.[24] Similar developments also surfaced in the United States, with the Fair Credit Reporting Act in 1970, which also contained data protection elements.
Significant developments in data protection law occurred when the European Union unified its data protection law through the General Data Protection Regulation of the European Union (EU GDPR), in 2016, and came into force on 25 May 2018. The GDPR is comprehensive, covering almost all processing personal data.[25] In general, data protection refers to the practice, protection, and binding rules that are put in place to protect personal information and ensure that data subjects continue to control the information. In short, the data owner must be able to decide whether or not to share some information, who has access, for how long, and for what reasons.

In the public discourse in Indonesia, the concept of privacy is often identified as a western (European) concept, as is human rights. This reason justifies the low level of public awareness about privacy, especially those related to protecting one's data. In the contemporary context, social media users in Indonesia openly state their real place of residence (home address), date, month, and year of birth; phone number; also kinship with parents or siblings. This shows that there is still an issue about consumers' awareness to protect privacy or personal data, as part of personal property.[26]

After the constitutional amendment - the 1945 Constitution, the right to privacy, including protection of personal data, is recognized as one of the constitutional rights of citizens. This is in line with the inclusion of a special chapter on human rights (bill of rights) in the amended constitution (Chapter XA-Article 28 A-J). Provisions regarding the guarantee of personal data protection can be found in Article 28G paragraph (1) of the 1945 Constitution which states, "Everyone has the right to protection of personal, family, honor, dignity and property under his control, and has the right to sense, safe and protection from the threat of fear to do or not do something that is a human right." Apart from constitutional protection, Indonesia's involvement as a state party to the International Covenant on Civil and Political Rights (ICCPR), which has been ratified by Law no. 12/2005, also affirms the obligation of the Indonesian government to protect the privacy and personal data of its citizens.

The draft of bill on Personal Data Protection also stipulates provisions regarding exceptions in the application of personal data protection. These exceptions apply:[27]

1) In the interests of national defense and security;

2) Necessary for the benefit of the judicial process following the provisions of the Legislation;

3) For the purposes of state administration and public interests, particularly economic interests or finance; 
4) For enforcement of professional code of ethics; and

5) for data aggregate processing intended for statistical and scientific research purposes.

Meanwhile, the Bill does not yet regulate the formation of an institution that functions as a regulator, supervisor, and controller (independent regulatory body), or a commission for personal data protection.[28] Eventually, this supervisory task is left to the government, under their respective sectors, in coordination with the Minister of Communication and Information Technology. This means that the Ministry of Home Affairs will supervise personal data related to demography, OJK will monitor personal data related to finance and banking, the Ministry of Health will monitor personal data related to patient medical records, the Ministry of Law and Human Rights will monitor personal data related to passport and legal data.

Ratification of the bill is an important agenda for legal development in this digital era. The government needs to ensure the security of public data by law. As many as 110 countries have laws specifically on the protection of personal data, 90 of which are countries with emerging markets.[29] The Personal Data Protection Act Regulation provides. the legal basis for the Indonesian nation, to maintain state sovereignty, state security, and protection of personal data belonging to Indonesian citizens, wherever such personal data is located.

The Personal Data Protection Act needs to regulate oversight of commercial transactions conducted by companies. The e-commerce sector has a high number of consumers. Shopping in this millennial style offers convenience in transactions. However, online shopping carries a fairly large level of risk, ranging from fraud, late or not arriving items, items not according to orders, to misappropriation of personal data.[30] Without a competent supervisory agency, e-commerce consumer data can be misused for various purposes that can harm the interests of the data owner.

The real conditions in e-commerce activities show that consumers are the weak party in each of these transactions, meaning that the technical rules related to the code of conduct of e-commerce activities are expected to be able to protect the interests of consumers through detailed per-consent from the privacy policies that apply in each activity. e-commerce should be agreed upon by both parties so that online marketplace system platform providers do not easily collect data for profit-oriented. In this context, the state must be present and be the party controlling the privacy policy formulated agreed upon by e-commerce service providers/sellers with consumers regarding privacy data carried out online. so that in this context, the standard privacy policy clauses which have many deficiencies can be immediately corrected so that consumers' rights are not violated.

In the European Union, there are legal regulations at the regional level governing data privacy protection in e-commerce activities. As in the EU Directive on the protection of Consumers in Respect of Distance Contract, 19 in this legal regulation regulate: consumer protection from unfair contract provisions, sales, and guarantees for the period of the sale, this is related to how harmonization and legal reform between European Union member countries to contract both consumer goods and services.[31]

Regarding the privacy policy in the online marketplace system in the European Union, it is regulated in Article 7 of the EU Directive on ECommerce and is more specifically regulated in Article 5 (3) of The Privacy and Electronic Communication Directive 2002 (PECD), which explains that the cookie technology in online The marketplace system has had a major impact on the violation of the privacy data of online consumers who are conducting e-commerce transactions, there needs to be an effort to ban this technology in all e-commerce activities which are mandatory to be obeyed.

All e-commerce activities, including companies that produce products to be marketed in e-commerce and banking companies that produce credit cards for consumers in the European Union, are required to make clear provisions and be obeyed by the parties through a privacy policy in accordance with the standards of the EU Directive.[32] In this privacy policy, electronic transactions must be honest and contain comprehensive information, both about the objectives and the process of processing this online data, so that the privacy rights of online consumers are not violated in e-commerce activities.

Apart from being applicable at the EU regional level, various regulations related to privacy policies in the online marketplace system are also applied in the national legal provisions of several countries in the European Union, not all EU countries were discussed in this part, the discussion is specifically for countries which have been established in making privacy policies in the online marketplace system, these countries are: France, Germany, and Great Britain.[34]

\section{CONCLUSION}

Legal relationships in e-commerce transactions are based on agreements made by the parties. Thus, the principles of agreement and contract legality are subject to the Criminal Code. The electronic contract is a variant that extends the agreement that was made conventionally. Currently, e-commerce consumer protection still uses the UUPK, which is the main law of consumer protection. This law is no longer sufficient to solve legal problems arising from electronic 
transactions. Meanwhile, the ITE Law has not been fully used to resolve consumer disputes. To protect the rights of e-commerce consumers, comprehensive regulations regarding the protection of personal data are needed. In addition, to resolve consumer disputes, it is necessary to strengthen the online dispute resolution mechanism and personal data security as a Consumer Protection Instrument. This study recommends further research that can compare the application of the PDP Law in several countries, especially regarding supervisory agencies that can control the use of consumer personal data by electronic system administrators and marketplace companies.

\section{AUTHORS' CONTRIBUTIONS}

Sugeng developed main ideas and formulated relevant theoretical frameworks. Meanwhile, Annisa Fitria, reviewed previous scientific papers and verified data and legal materials.

\section{ACKNOWLEDGMENTS}

This work would not have been possible without support of University of Bhayangkara Jakarta Raya and University of Esa Unggul. We are grateful to all of those with whom we have had the pleasure to work during this project.

\section{REFERENCES}

[1] A. Rohendi, "Ookoko," J. Ecodemica J. Ekon. Manajemen, dan Bisnis, vol. 3, no. 2, pp. 474-488, 2015, [Online]. Available: http://ejournal.bsi.ac.id/ejurnal/index.php/ecodemi $\mathrm{ca} /$ article/view/34.

[2] M. Syamsudin and F. A. Ramadani, "Perlindungan Hukum Konsumen Atas Penerapan Klausula Baku (Kajian Putusan Nomor 26/P.BPSK/12/2014, Nomor 15/PDT.G/2015/PN.SBY, dan Nomor 184 K/PDT.SUS-BPSK/2016)," J. Yudisial, vol. 11, no. 1, pp. 91-112, 2018.

[3] R. Hartanto and J. P. Ramli, "Hubungan Hukum Para Pihak Dalam Peer To Peer Lending," J. Huk. Ius Quia Iustum, vol. 25, no. 2, pp. 320-338, 2018, doi: 10.20885/iustum.vol25.iss2.art6.

[4] M. Išoraitė and N. Miniotienè, "Electronic Commerce: Theory and Practice," IJBE (Integrated J. Bus. Econ., vol. 2, no. 2, p. 73, 2018, doi: 10.33019/ijbe.v2i2.78.

[5] OJK, "Perkembangan Fintech Lending (Pendanaan Gotong Royong on-Line)," Otoritas Jasa Keuang., no. 28, pp. 2014-2017, 2018, [Online]. Available: https://www.ojk.go.id/id/berita-dan-

kegiatan/siaran-pers/Documents/Pages/SiaranPers-Satgas-Kembali-Temukan-182-Fintech-PeerTo-Peer-Lending-Tanpa-Izin.

[6] K. Garvey et al., "The 2nd Asia Pacific Region Alternative Finance Industry Report," no.
September, pp. 1-103, 2018, [Online]. Available: https://www.jbs.cam.ac.uk/fileadmin/user_upload/r esearch/centres/alternative-

finance/downloads/2017-12-cultivating-

growth.pdf.

[7] D. Bholat and U. Atz, "Peer-to-peer lending and financial innovation in the UK," Law Financ. after Financ. Cris. Untold Stories UK Financ. Mark., no. 598, pp. 27-47, 2016, doi: $10.4234 / 9781315676579$.

[8] O. Havrylchyk, C. Mariotto, and T.-U.- Rahim, "What Drives the Expansion of the Peer-to-Peer Lending?," SSRN Electron. J., 2016, doi: 10.2139/ssrn.2841316.

[9] K. Giri, N. Sari, I. Perdana, And P. Wardani, "Evaluasi Sistem Pegendalian Internal Terhadap Pengelolaan Dana Kas di Lembaga Perkreditan Desa (LPD) Desa Pakraman Anturan," J. Ilm. Akunt. dan Humanika, vol. 7, Sep. 2019, doi: 10.23887/jinah.v7i2.19957.

[10] H. Yin, "P2P lending's business models, risks and regulation," Int. J. Ind. Bus. Manag., pp. 1-4, 2017, doi: 10.28933/ijibm-2017-03-0801.

[11] D. Paryadi, "Pengawasan E Commerce Dalam Undang-Undang Perdagangan Dan UndangUndang Perlindungan Konsumen," J. Huk. Pembang., vol. 48, no. 3, p. 652, 2018, doi: 10.21143/jhp.vol48.no3.1750.

[12] P. Perales Viscasillas, "The role of arbitral institutions under the 2010 UNCITRAL Arbitration Rules," pp. 26-76, 2014, [Online]. Available: https://core.ac.uk/download/pdf/30276825.pdf.

[13] E. S. Soegoto, A. Christiani, and D. Oktafiani, "Development of E-Commerce Technology in World of Online Business," IOP Conf. Ser. Mater. Sci. Eng., vol. 407, no. 1, 2018, doi: 10.1088/1757899X/407/1/012031.

[14] A. I. K. P. N. S. Nico Pratama, "Hukum Kontrak Dalam Perspektif Komparatif (Menyorot Perjanjian Bernama Dengan Perjanjian Tidak Bernama)," Serambi Huk., vol. 8, no. 02, pp. 138 $151,2015$.

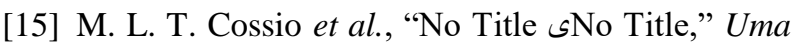
ética para quantos?, vol. XXXIII, no. 2, pp. 8187, 2012, doi: 10.1007/s13398-014-0173-7.2.

[16] A. Milne and P. Parboteeah, The Business Models and Economics of Peer-to-Peer Lending, no. 17. 2016.

[17] W. Yingxi and D. Shi, “温颖茜 1, 滴 石 2, 3 ( 1 .," vol. 5, no. 10, pp. 58-70, 2019.

[18] T. Uyen and H. Ha, "the Sharing Economy and Collaborative Finance: the Case of P2P Lending in 
Vietnam," J. Ilm. Ekon. Bisnis, vol. 22, no. 2, pp. 84-93, 2017, doi: 10.5281/zenodo.2598868.

[19] A. Jazuli, "Urgensi Pembentukan Jabatan Fungsional Dokumentalis Hukum Hukum Nasional (The Urgency for Establishment of Functional Position of Legal Documenter to Support National Legal Documentation and Information Network )," J. Ilm. Kebijak. Huk., vol. 13, no. 2, pp. 185-200, 2019.

[20] A. Setiantoro, F. D. Putri, A. Novitarani, and R. Njatrijani, "Urgensi Perlindungan Hukum Konsumen Dan Penyelesaian Sengketa ECommerce Di Era Masyarakat Ekonomi Asean," J. Rechts Vinding Media Pembin. Huk. Nas., vol. 7, no. 1, p. 1, 2018, doi: 10.33331/rechtsvinding.v7i1.220.

[21] M. F. Aziz and M. A. Hidayah, "Perlunya Pengaturan Khusus Online Dispute Resolution (Odr) Di Indonesia Untuk Fasilitasi Penyelesaian Sengketa E-Commerce," J. Rechts Vinding Media Pembin. Huk. Nas., vol. 9, no. 2, p. 275, 2020, doi: 10.33331/rechtsvinding.v9i2.449.

[22] M. A. Mansyur and H. Kamil, "Kajian Hukum Online Dispute Resolution (ODR) Di Indonesia Berdasarkan Undang-Undang Nomor 30 Tahun 1999," J. Pembaharuan Huk., vol. 1, no. 2, p. 111, 2014, doi: 10.26532/jph.v1i2.1461.

[23] S. Rosadi, "Protecting Privacy on Personal Data in Digital Economic Era : Legal Framework in Indonesia," Brawijaya Law J., vol. 05, no. 01, pp. 143-157, 2018, doi: 10.21776/ub.blj.005.01.09.

[24] A. Skendzic, B. Kovacic, and E. Tijan, "General data protection regulation - Protection of personal data in an organisation," 201841 st Int. Conv. Inf. Commun. Technol. Electron. Microelectron. MIPRO 2018 - Proc., no. February 2019, pp. 1370-1375, 2018, doi: 10.23919/MIPRO.2018.8400247.

[25] Privacy International, "The Keys to Data Protection: A guide for policy engagement on data protection," no. August, p. 100, 2018, [Online].

Available: https://privacyinternational.org/sites/default/file s/2018-09/Data Protection Complete.pdf.

[26] K. Mania, "Online dispute resolution: The future of justice," Int. Comp. Jurisprud., vol. 1, no. 1 , pp. 76-86, 2015, doi: 10.1016/j.icj.2015.10.006.

[27] A. Pengantar and N. Nasional, "Memerhatikan perlindungan hak atas privasi dalam pengaturan dan praktik penyadapan di Indonesia 1," pp. 17, 2014.

[28] W. Djafar, "Perlindungan Data Pribadi di
Indonesia: Lanskap, Urgensi, dan Kebutuhan Pembaruan," J. Becoss, vol. 1, no. 1, pp. 147$154,2019$.

[29] P. Guarda, "Data Protection , Information Privacy, and Security Measures : an essay on the European and the Italian Legal Frameworks," Ciberspaizo e Dirit., no. December, pp. 65-92, 2008.

[30] S. F. Anggraeni, "Polemik Pengaturan Kepemilikan Data Pribadi: Urgensi Untuk Harmonisasi Dan Reformasi Hukum Di Indonesia," J. Huk. Pembang., vol. 48, no. 4, p. 814, 2018, doi: 10.21143/jhp.vol48.no4.1804.

[31] R. A. Nugraha, "Perlindungan Data Pribadi dan Privasi Penumpang Maskapai Penerbangan pada Era Big Data," Mimb. Huk. - Fak. Huk. Univ. Gadjah Mada, vol. 30, no. 2, p. 262, 2018, doi: 10.22146/jmh.30855.

[32] R. Wong, "The Data Protection Directive 95/46/EC: Idealisms and realisms," Int. Rev. Law, Comput. Technol., vol. 26, no. 2-3, pp. 229-244, 2012, doi: $10.1080 / 13600869.2012 .698453$.

[33] S. Park et al., "A comparative study on data protection legislations and government standards to implement digital forensic readiness as mandatory requirement," DFRWS 2018 EU - Proc. 5th Annu. DFRWS Eur., vol. 24, pp. S93-S100, 2018, doi: 10.1016/j.diin.2018.01.012. 